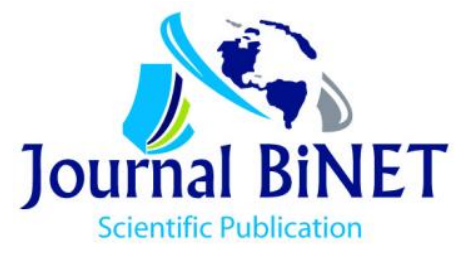

Volume 03, Issue 02, Article no. 22, pp. 195-206

http://www.journalbinet.com/jstei-volume-03.html

Original Research Paper

\title{
Responses of IBA on rooting, biomass production and survival of branch cuttings of Santalum album L., a wild threatened tropical medicinal tree species
}

\section{Md. Salim Azad*, Md. Jahidul Alam, Abdus Subhan Mollick and Md. Abdul Matin}

Forestry and Wood Technology Discipline, Khulna University, Khulna-9208, Bangladesh

\section{Article info.}

Key Words:

Vegetative propagation, Branch cutting, Rooting, Propagator, IBA, Santalum album

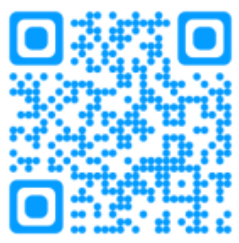

Received: 13.04 .2016 Published: 01.06.2016

Corresponding author*: azadfwt@yahoo.com

\section{ABSTRACT}

Clonal propagation is important for the conservation of native, wild and threatening tree species. The study investigates the opportunities of rooting of branch cuttings of Santalum album treated with 0, 0.4, 0.6 and 0.8\% indole-3butyric acid (IBA) in a non-mist propagator. A total of four hundreds eighty cuttings were used to assess the rooting ability of this species. The study revealed significant differences $(p<0.05)$ of rooting percent, average root number per cutting and average root length among the treatments. Rooting success varied 1.32-fold (70-92.6\%), 3.8-fold (5-19) and 3.1-fold (3.1-9.6 cm) in rooting percentage, average root number per cutting and average root length respectively among the treatments. The maximum and minimum rooting success were observed in $\mathrm{T} 3$ and $\mathrm{TO}$ in all cases except in root number per cutting. In this case T2 performed better than others. The result exposed significant differences ( $p<0.05)$ of sprouting percent (1.32-fold: $62.3-83.3 \%)$ among the treatments but no significant difference $(p>0.05)$ of number of sprouts per cutting (2.5-fold: 2-5) and number of leaves per cutting (1.7-fold: 10-17). Maximum and minimum sprouting percent was showed similar fashion of rooting percent. The results also exposed significant differences $(p<0.05)$ of biomass production in adventitious roots and shoots among the treatments. Biomass production was significantly $(p<0.01)$ higher in adventitious shoots than those of roots. The overall survival of rooted cutting was higher in control (90.56\%) than others but showed no significant differences ( $p>0.05$ ) among the treatments. It can be recommended not to use IBA for rooting of branch cuttings of S. album.

\footnotetext{
Citation (APA): Azad, M. S., Alam, M. J., Mollick, A. S. \& Matin, M. A. (2016). Responses of IBA on rooting, biomass production and survival of branch cuttings of Santalum album L., a wild threatened tropical medicinal tree species. Journal of Science, Technology and Environment Informatics, 03(02), 195-206.

(c) 2016, Azad et al. This is an open access article distributed under terms of the Creative Common Attribution 4.0 International License.
} 


\section{Introduction}

Clonal propagation is a way of sustainable use of genetic resources designed to achieve particular traits and thereby, conservation. Within very short time, huge quantity of quality planting materials can be produced through vegetative propagation. In the tropics, branch cutting, stem cutting and nodal cutting were effectively experienced for clonal propagation (Dick and Aminah, 1994; Leakey et al., 1994; Tchoundjeu and Leakey, 2001; Hartmann et al., 2002; Itoh et al., 2002; Husen, 2003; Husen et al., 2003; Tchoundjeu et al., 2004; Abdullah et al., 2006; Husen and Pal, 2006; Husen and Pal, 2007; Matin et al., 2006; Tchoundjeu et al., 2006; Baul et al., 2010). Rooting of cuttings is a model technique of clonal propagation due to less expensive and less time consuming. This technique is very excellent to continue certain desirable traits of an endangered species (Hartmann et al., 2002; Tchoundjeu et al., 2004). Nevertheless, the recalcitrant nature of the seeds of many species and seed periodicity (irregular nature of seed production) make seed collection problematic (Itoh et al., 2002). To overcome these problems, many studies have been carried out to examine the ability of successful rooting of cutting of a considerable number of tropical forest tree species (Dick and Aminah, 1994). Rooting success of cuttings depends on species variation, growth hormone and concentration of hormone as well (Leakey et al., 1990; Leakey et al., 1994; Tchoundjeu et al., 2002). But no realistic effort has been taken to conserve Santalum album through branch cuttings.

Santalum album L., is a threatened (Asian Regional Workshop, 1998) small tropical tree species of Santalaceae family, commonly known as sandalwood or Chandon. It is native to semi-arid areas of Indian sub-continent and is now planted in China, Sri Lanka, Indonesia, Malaysia, the Philippines and Northern Australia. It is an evergreen hemiroot parasite tree, grows well from coastal dry forest up to $700 \mathrm{~m}$ altitude with a temperature range from $0-38^{\circ} \mathrm{C}$ where annual rainfall is between 500 to 3000 $\mathrm{mm}$. S. album grows normally in sandy or stony red soil but can be found in wide range of soil type. It is considered as luxurious tree species for its high class fragrant heartwood. The heartwood contains sandal oil (about 6\%) which has been used in perfumes, cosmetics and medicine industries. Sandalwood oil is widely used for the treatment of coldness, fever, weakness, skin diseases, bronchitis, hear diseases, infection of urinary system, liver and gall bladder complaints etc. (Misra and Dey, 2013a). It is extremely used in incense sticks (locally known as agarbati) industries in the Indian sub-continent (Srinivasan et al., 1992). Anti-oxidant, anti-microbial, and anti-hyperglycaemic potentials have been noticed in many research articles of this species (Misra and Dey, 2012; Misra and Dey, 2013b). But there are some problems associated with seed production and seedlings growth. Due to out-breeding nature of this species, seedlings are strongly heterozygous (Srimathi et al., 1995). However, S. album is strongly recalcitrant in nature which limits the success of propagation (Uniyal et al., 1985; Rao and Bapat, 1992). Besides, age of mother plant (around 20 years) is very important for quality seed production. But the mother trees of this species are declining at an alarming rate due to high commercial value, which creates problems of producing quality seeds for germination. Some associate factors like germination media, light intensity, aeration, temperature, and pest and diseases also create problems of seed germination and seedlings growth. Londoh (whitish decay fungi), sandal spike diseases and leaf worm can quickly damage the regeneration which narrowed the gene pool of this species. Therefore, conservation of this species is under threats. Under this situation, vegetative propagation can be a means to conserve this species. Development of rooting of stem / branch cutting may be the fastest, easiest and inexpensive way for propagation. For large scale plantation, vegetative reproduction of this species could be a possibility in forest tree improvement. The possibilities of producing disease resistant variety of this species are also achievable through vegetative propagation. Vegetative propagation of industrial species is an alternative option for maximizing the end uses within very short period (Alam, 2001). Last twenty five years, a lot of studies were conducted on propagation of this species (Table 01), especially in vitro (micro-propagation) which is very expensive for conservation for the local users. Only few studies were conducted on rooting of cuttings of this species (Batabyal et al., 2014). But no study has been conducted on effects of IBA on rooting and sprouting of branch cutting, biomass production of adventitious shoots and roots and survival of cuttings. Batabyal et al. (2014) noticed responses of some phyto-hormones for vegetative propagation of this species with stem cuttings of different high concentrations without mentioning the rooting, sprouting and survival 
success, that was a problem for the local people who were actually depend on this species for their livelihood. Thus, an attempt has been taken to conduct this experiment. It is essential to establish the suitable treatment for the best possible rooting of this species from clonal propagation. The goal of this study is to assist preserving this species from biodiversity and economic point of views. Thus, this experiment was intended to examine the opportunity of vegetative propagation of $S$. album through investigating the effects of different IBA concentrations on the rooting ability of juvenile branch cuttings from mother tree.

Table 01. Study of seed germination, seedling growth and propagations related studies with Santalum album

\begin{tabular}{lll}
\hline Research study & Using parts & References \\
\hline $\begin{array}{l}\text { Seed dormancy } \\
\text { Seed germination }\end{array}$ & $\begin{array}{l}\text { Seeds } \\
\text { Seeds }\end{array}$ & $\begin{array}{l}\text { Jayawardena et al., 2015 } \\
\text { Sahai and Shivanna, 1984; XiaoJin et } \\
\text { al., 2010 }\end{array}$ \\
$\begin{array}{l}\text { Seedling growth } \\
\text { Growth response (to gibberellins) } \\
\text { Plant regeneration }\end{array}$ & $\begin{array}{l}\text { Seedlings } \\
\text { Seedlings } \\
\text { Clonal seed orchards }\end{array}$ & $\begin{array}{l}\text { Sahai and Shivanna, 1984; } \\
\text { Xiaojin et al., 2010 }\end{array}$ \\
$\begin{array}{l}\text { Vegetative propagation } \\
\text { Vegetative propagation }\end{array}$ & $\begin{array}{l}\text { Grafting, air layering } \\
\text { Vegetative propagation }\end{array}$ & $\begin{array}{l}\text { Singh et al., 2013 } \\
\text { Srimathi et al., 1995 }\end{array}$ \\
Vegetative propagation & Grafting & Batabyal et al., 2014 \\
Micro-propagation & Air layering & Srimathi et al., 1995 \\
& Root suckers & Srimathi et al., 1995 \\
Micro-propagation & Tissue culture & Srimathi et al., 1995 \\
In vitro propagation & Rao and Bapat, 1978; Rao and \\
Anti-bacterial efficiency & Nodal shoot segments & Bapat, 1992; Rao et al., 1983 \\
Antioxidant potentials & Sanjaya et al., 2006 \\
\hline & Prgan culture & Rao et al., 1983 \\
\hline
\end{tabular}

\section{Materials and Methods}

Study site: The study was carried out in the nursery of Forestry and Wood Technology (FWT) Discipline of Khulna University $\left(22.802^{\circ} \mathrm{N}\right.$ latitude and $89.533^{\circ} \mathrm{E}$ longitude), Bangladesh. The study area is about $4 \mathrm{~m}$ above the mean sea level. It is a fertile, floodplain, lowland conquered by alluvial soils (BBS, 2001) close to the Sundarbans, Bangladesh, the single largest mangrove forest in the world. The climate is familiar as subtropical in nature; particularly winter, summer, and monsoon are the distinctive seasons, more or less related to the other regions of the country. Temperature deviation is very little in winter $\left(7\right.$ to $\left.12^{\circ} \mathrm{C}\right)$ but it rises up to $25-32^{\circ} \mathrm{C}$ in summer. It increases up to $40^{\circ} \mathrm{C}$ very occasionally (BBS, 2001).

Construction of low cost propagator: The study was conducted in a low cost non-mist propagator. The propagator was made of wood and transparent polythene sheet documented by Leakey et al. (1990) and adapted by Kamaluddin et al. (1996). The structure was rectangular in shape (1.8 m x $1 \mathrm{~m} \mathrm{x}$ $1.5 \mathrm{~m}$ ) (Azad and Matin, 2015). It was enclosed with white polythene sheet and strongly fixed with a lid to be airtight. The structure was placed on the floor of the nursery made of concrete. Polythene sheet was used to the base of the structure to be watertight. Course sand, fine gravels and small stones were used as propagation media. The propagator was placed under the shade to shun too much heat accretion. Mean temperature was maintained between $25-32^{\circ} \mathrm{C}$ within the propagator throughout rooting period. The propagator was opened for a little early in the morning and at late afternoon to assist gas replacement. The lid of the propagator was opened for checking the status of cutting and at that time water spraying was done to uphold a lower vapor pressure deficit resulting humid environment within the propagator during the propagation period. Air temperature was measured both inside and outside the rooting propagator by the thermometers. 
Cutting materials and design of the experiment: Mother trees (five to seven years old) were selected from different home gardens of Khulna, Bangladesh as candidate trees for collection of cutting materials for this purpose. Nodal cuttings, approximately 12-14 cm in length (average) were made for rooting trails from the selected juvenile branches of demarcated mother trees. The cutting materials were enclosed instantly with polythene bags to defend moisture loss and transported to the propagation site. Age of mother trees, length of cuttings, diameter of cuttings and position of cuttings were apathetic among the treatments to keep away from the variation other than treatments. Diathane M45 solution was used for immersion of cuttings to shun fungal attack. The cuttings were then put under shade for half an hour in open air. This experiment was conducted with two phases, at the beginning (first phase), we started with low concentration of IBA (control, $0.1,0.2$ and $0.3 \%$ of IBA) to observe the rooting ability but we didn't find any significant difference of rooting of cuttings among the treatments though rooting success was satisfactory (on average 74\%). Thus, we decided to start the experiment (final phase) with higher concentration of IBA to observe rooting and sprouting ability, biomass accumulation in adventitious roots and shoots and also to observe survival success. The cuttings were treated with four treatments of Indole-3-butyric acid (IBA) solution. The treatments were T0 (control), T1 $(0.4 \%$ IBA), T2 $(0.6 \%$ IBA), and T3 $(0.8 \%$ IBA). The treated cuttings were placed in the propagator in a completely randomized design. Thirty cuttings were used with four replications in each treatment. So, a total of 480 ( $30 \times 4 \times 4)$ cuttings were placed under four different treatments with four replications.

Inspection for root and shoot development: The observation of rooting success was conducted once a week but it was first observed fifteen days after cutting placement in the propagator. Cuttings were considered as rooted only when one root exceeded at least $1 \mathrm{~cm}$ long (Figure 01). The observation of root and shoot development in the propagator was completed within forty five days after putting the cuttings materials into the rooting media. After completion of root and shoot development, the cuttings were subjected to harden before transfer them into polybag. For hardening of the rooted cuttings, the propagator was kept open every alternate day at night for a week and then another three days for every night. This process was also conducted at day time for a week every alternate day and then another three days regularly to adjust the adverse situation outside the propagator. Ten rooted cuttings from each treatment were randomly taken for green and oven dry biomass calculation. All the roots and shoots per cutting were separated with the help of forceps for this purpose. The green weight per cutting was measured separately by using electric balance immediately after separation of roots and shoots from the cuttings. For oven dry weight, the roots and shoots per cuttings were separately placed into an electric oven at $80^{\circ} \mathrm{C}$ for $24 \mathrm{~h}$ and taken the first weight. The weight was measured every hour until obtained the constant weight. The weight of biomass was taken with a digital balance. All the rooted cuttings (except the cuttings used for biomass calculation) were transferred into polybags filled with soil and decomposed cow-dung with a ratio of 3:1 (Azad and Matin, 2015). The observations on rooting success, length of the longest root, number of roots/ sprouts/ leaves per cuttings were recorded prior to transfer the rooted cuttings into polybags. A centimeter scale was used to measure the lengths of roots.

For the assessment of survival success, rooted cutting were put in open sun for 120 days to grow. Watering and weeding were done when necessary. During the study, no supplementary compost, manure, fertilizer and pesticide were used.

Data analysis: Statistical data analysis was conducted with the help of MS Excel 2007, Statistical Package SPSS (v. 20.0). Rooting, sprouting and survival success were uttered in percentage. Kaleida graph (version 4) was used for descriptive statistics for quantitative parameters. Analysis of variance (ANOVA) was conducted to check the significant difference of rooting percentage, sprouting ability, number of roots per cutting, number of sprouts per cutting, number of leaves per cutting, green and oven dry weight of adventitious roots and shoots in cuttings and survival of transplanted cuttings among the treatments. The Mann-Whitney test was carried out to identify the differences in the mean values of green and oven dry weight between adventitious shoots and roots. Prior to analyze ANOVA, the data recorded in percent were carried out arcsine transformation. 

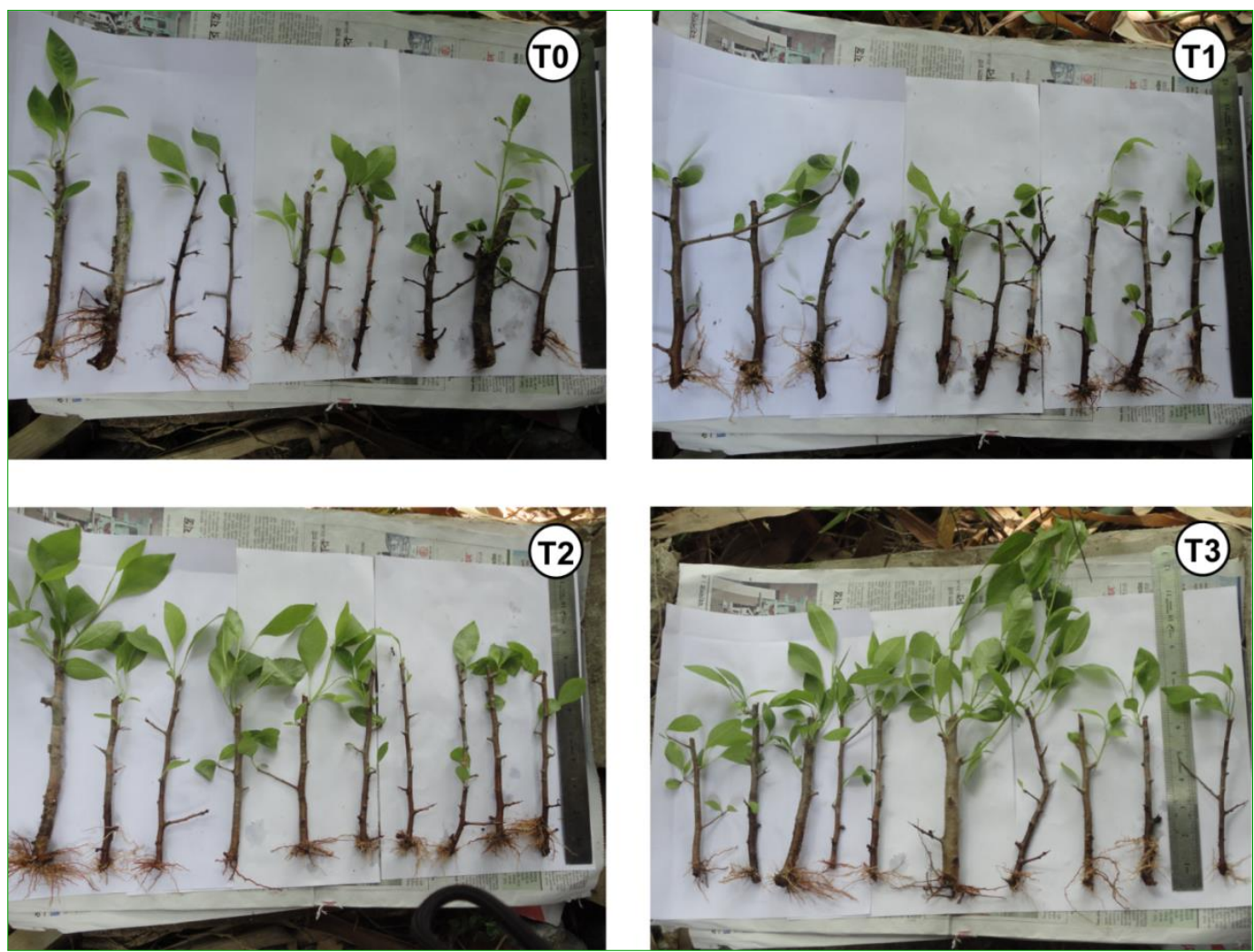

Figure 01. Rooting and sprouting responses under various treatments: T0: control, T1: 0.4\% IBA, T2: 0.6\% IBA, and T3: 0.8\% IBA.
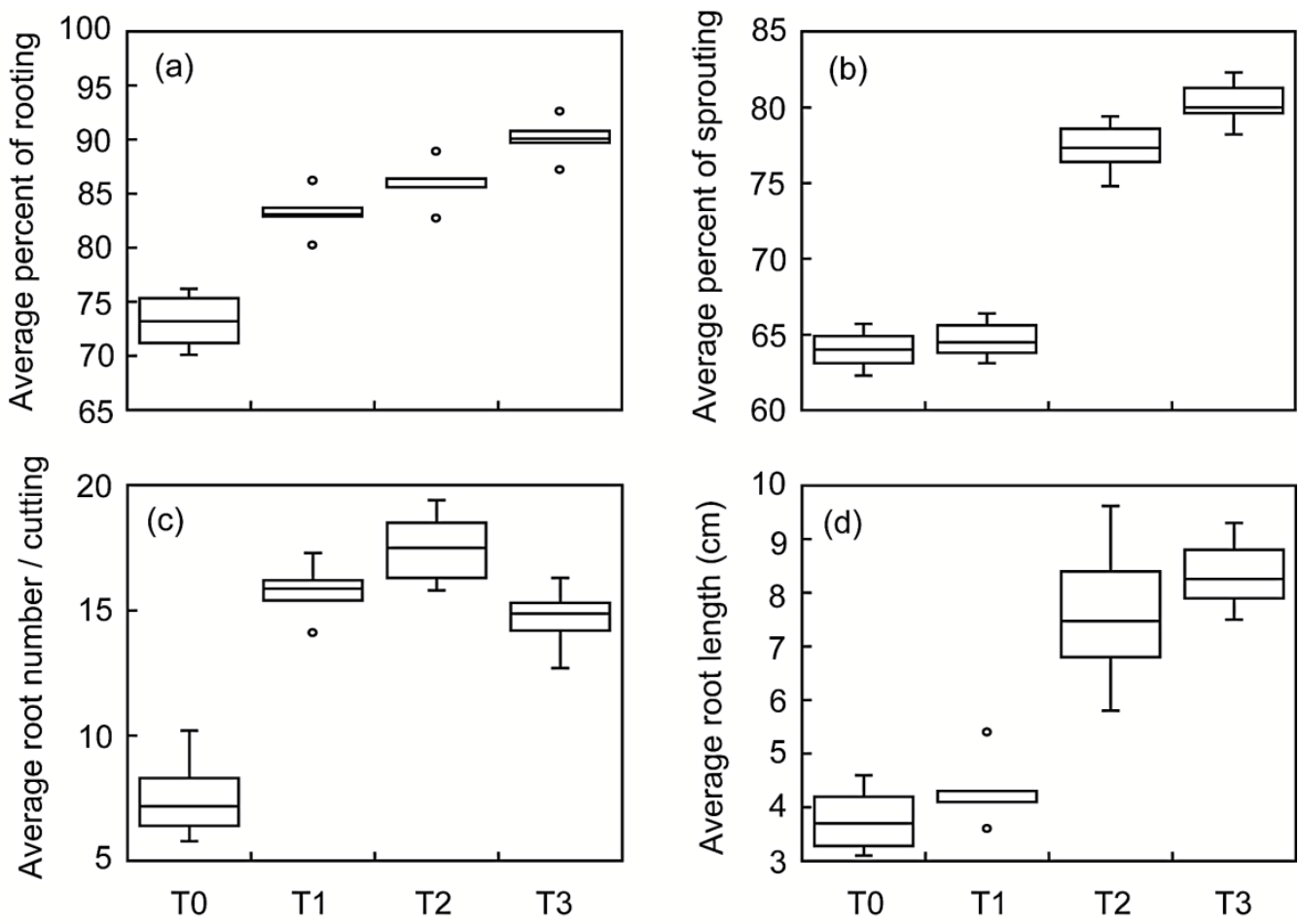

Treatments

Figure 02. Different treatment effects on a) average percent of rooting, b) average percent of sprouting, c) root number per cutting, and d) average root length $(\mathrm{cm})$. T0: control, T1: 0.4\% IBA, T2: 0.6\% IBA, and T3:0.8\% IBA. 


\section{Results}

\section{Rooting ability of cuttings}

The cuttings of S. album rooted well in the present study (Figure 01). Rooting percent was varied 1.32fold (70.1 - 92.6\%); average root number per cutting, 3.8-fold (5-19); and average root length, 3.1-fold $(3.1-9.6 \mathrm{~cm})$ among the various IBA treatments. The highest rooting percent was observed in $0.8 \%$ IBA concentration (T3) and lowest rooting percent was observed in control (T0). The rooting percent revealed significant differences $(\mathrm{p}<0.01)$ with increasing IBA concentration. Again the number of roots per cutting was significantly $(\mathrm{p}<0.01)$ increased with IBA treatments. The highest average number of roots per stem was observed 17.5 in $0.6 \%$ IBA and the lowest average number of roots per stem were observed 7.6 in control. The average longest root was also significantly $(p<0.01)$ increased with the concentration of IBA. The average longest root was observed $3.8 \mathrm{~cm}, 4.3 \mathrm{~cm}, 7.6 \mathrm{~cm}$ and $8.3 \mathrm{~cm}$ in control, 0.4\% IBA, 0.6\%IBA, and 0.8\%IBA treatments respectively (Figure 02).

\section{Sprouting ability of cuttings}

The cuttings of $S$. album sprouted also well. Sprouting percent was varied 1.32 -fold (62.3 - 83.3\%); number sprouts per cutting, 2.5-fold (2-5); and number of leaves per cutting, 1.7-fold (10-17) among the various IBA treatments. The highest sprouting percent was observed in $0.8 \%$ IBA concentration (T3) and lowest sprouting percent was observed in control (T0) (Figure 02b). The sprouting percent revealed significant differences $(\mathrm{p}<0.01)$ with the IBA treatments. Again the number of sprouts per cutting showed no significant difference $(p>0.05)$ with increasing IBA treatment. The highest average number of sprouts per stem was observed 3.12 in $0.8 \%$ IBA and the lowest average number of sprout per cutting were observed 2.54 in control (Figure 03a). The average leaves number per cutting also showed no significant difference ( $\mathrm{p}>0.05)$ with increasing the concentration of IBA. The average highest number of leaves was observed 13.9 in $0.8 \%$ IBA and the average lowest number of leaves were found 11.48 in control (Figure 03b).
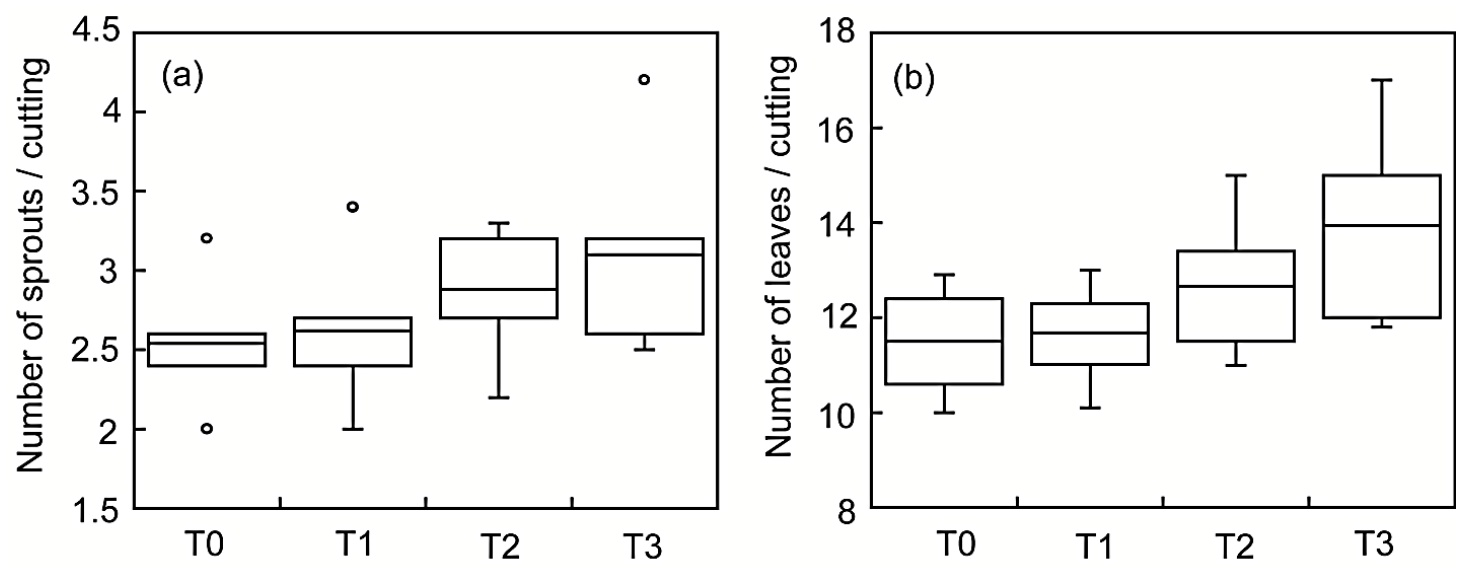

Treatments

Figure 03. Effects of various concentration of IBA on a) number of sprouts per cutting, and b) number of leaves per cuttings. T0: control, T1: 0.4\% IBA, T2: $0.6 \%$ IBA, and T3: $0.8 \%$ IBA.

\section{Biomass production}

Various treatments of IBA promoted the growth and biomass production of adventitious shoots and roots in cuttings (Figure 04). Green weight of shoots varied 1.52-fold (11.32-17.33 gm/cutting), dry weight of shoots 1.67-fold (2.59-4.32 gm/cutting), green weight of roots 2.2-fold (2.5-5.5 gm/cutting, and dry weight of roots 2.59-fold (0.54-1.4 gm/cutting). The highest growth and biomass production in shoots and roots were observed in cuttings treated with $0.8 \%$ IBA and lowest growth and biomass were observed in control (Figure 04 ). Green and oven dry weight of adventitious shoots and roots in cuttings 
revealed significant differences $(\mathrm{p}<0.05)$ with the IBA treatments. Results also showed higher growth and biomass production of adventitious shoots in cuttings than those of roots in cuttings (Figure 04). The Mann-Whitney test reveled significant difference $(p<0.01)$ of green and oven dry weight between adventitious shoots and roots.

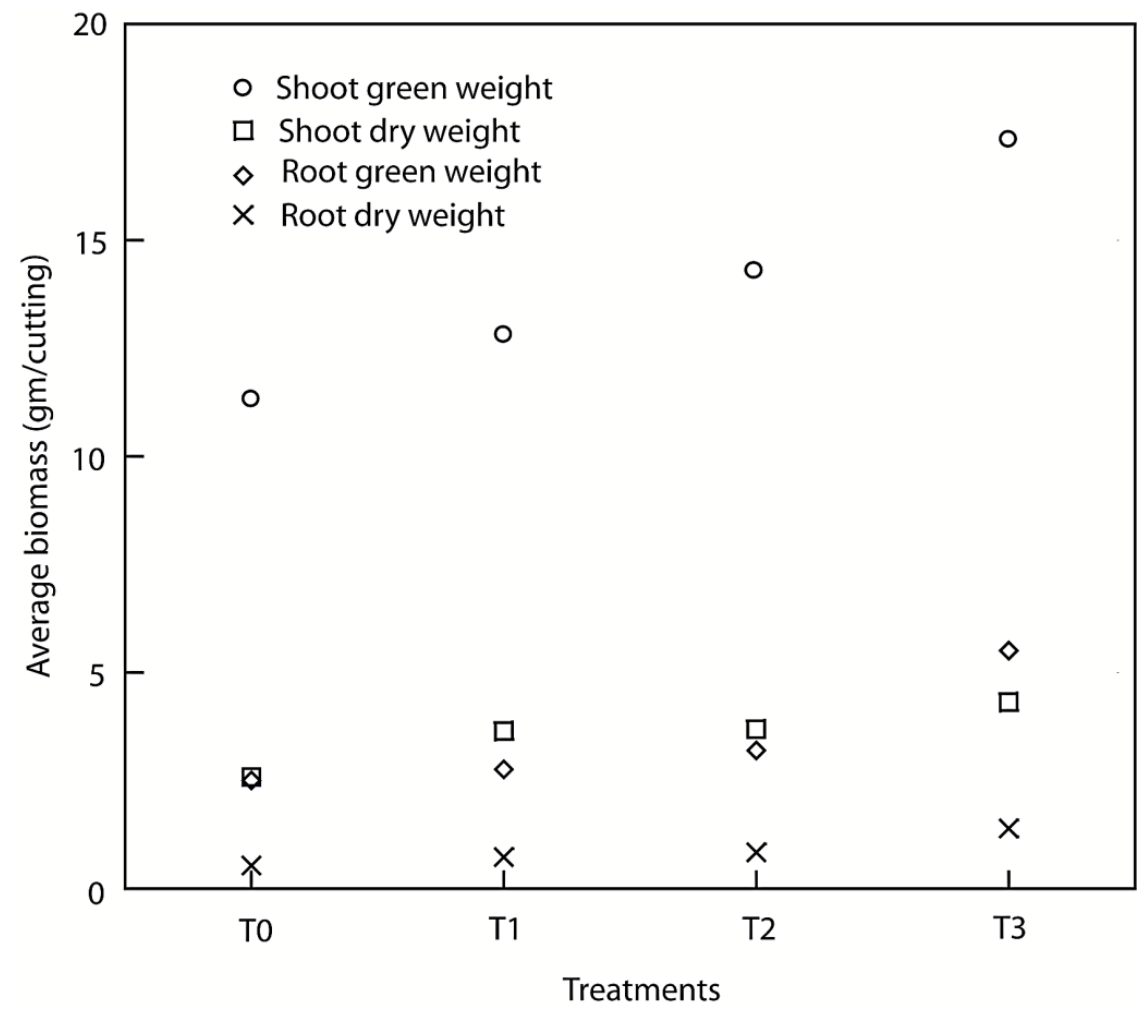

Figure 04. Specific responses to IBA treatments on biomass production. T0: control, T1: 0.4\% IBA, T2: $0.6 \%$ IBA, and T3: 0.8\% IBA.

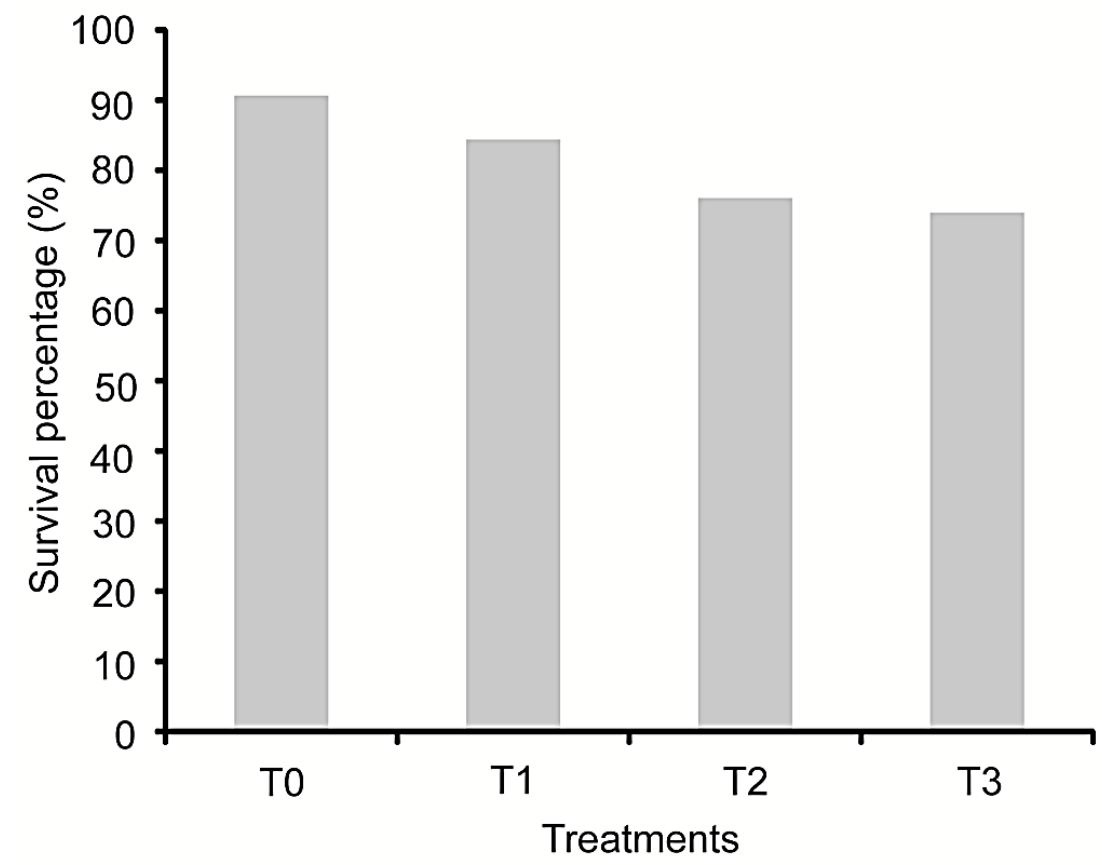

Figure 05. Survival percentage of rooted cuttings four months after transferring to polybags under different IBA treatments. T0: control, T1: 0.4\% IBA, T2: 0.6\% IBA, and T3: $0.8 \%$ IBA. 
J. Sci. Technol. Environ. Inform. 03(02): 195-206 | Azad et al. (2016)

EISSN: 2409-7632, www.journalbinet.com

DOI: http://dx.doi.org/10.18801/jstei.030216.22

\section{Survival of rooted cuttings}

Overall survival of rooted cuttings was very high four months after transferring from propagator to poly-bags. Rooted cuttings showed no significant differences of survival among IBA treatments ( $p>0.05$ ). Highest survival was found $90.56 \%$ in control and the lowest was $74.12 \%$ in T3 (Figure 05).

\section{Discussion}

Different rooting hormones were used for macro clonal propagation of forest tree species from branch or stem or nodal cuttings. Several authors documented rooting success of branch cuttings of different tropical forest trees (Leakey et al., 1990; Tchoundjeu and Leakey, 2001; Husen et al., 2003; Husen, 2003; Husen and Pal, 2006; Husen and Pal, 2007; Abdullah et al., 2005; Abdullah et al., 2006; Baul et al., 2010). IBA plays a significant role in rooting of various tropical forest tree species (Leakey et al., 1992; Ofori et al., 1996; Berhe and Negash, 1998; Negash, 2002; Husen et al., 2003; Tchoundjeu et al., 2002; Tchoundjeu et al., 2004; Abdullah et al., 2006; Husen and Pal, 2007; Amri et al., 2009; Baul et al., 2010). The use of IBA for rooting ability depends on the concentration of IBA among different species. In this study, the highest rooting percent of cuttings was observed in $0.8 \%$ IBA treatment (T3).The study also revealed gradual increase of rooting percent with increasing IBA concentration $(0.4-0.8 \%$ IBA $)$ but rooting percent with control (T0) was also satisfactory (73.2\%). Opuni-Frimpong et al. (2008) observed similar results of Khaya anthotheca and Khaya ivorensis cuttings for rooting. They observed rooting percent increased with increasing IBA (0.2-0.8 \% IBA) concentration. The result of this study is a contrast to Aminah et al. (1995); Abdullah et al. (2006); Baul et al. (2008). Aminah et al. (1995) noticed that the highest rooting percent of cutting of Shorea leprosula stem cuttings was observed with $0.2 \%$ IBA concentration then further decrease with increasing IBA concentration (0.4- 0.8\% IBA). Abdullah et al. (2006) observed highest percent of rooting of Psidium guajava with the application of $0.2-0.4 \%$ IBA but it reduced with further increasing of IBA concentration. Baul et al. (2008) found highest rooting percent on Stereospermum suaveolens stem cutting with $0.4 \%$ IBA comparing to control and at low concentration of IBA treatment (0.1-0.2\% IBA) but rooting percent with control was much higher than $0.1-0.2 \%$ IBA. Higher rooting percent from control (without IBA) for $S$. album may be due to the higher level of endogenous auxin content in the cuttings. Hartmann et al. (1990) documented variation of auxin content at time of severance.

Higher concentration (0.4-0.8\% IBA) had a significant influence on average number of roots per cutting and the length of longest root of $S$. album branch cutting. Several researchers also noticed significant differences of root number per cutting among IBA treatments on Khaya ivorensis (Tchoundjeu and Leakey, 2000), Juniperus procera (Negash, 2002), Tectona grandis (Husen and Pal, 2007), Dalbergia melanoxylon (Amri et al., 2009). In contrast, a number of researchers observed no significantdifferences of root number per cutting and the length of roots with IBA treatments on Irvingia gabonensis (Shiembo et al., 1996), Milicia excels (Ofori et al., 1996), Pausinystalia johimbe (Tchoundjeu et al., 2004), Stereospermum suaveolens (Baul et al., 2008) and Holarrhena pubescens (Baul et al., 2010). It may be due to lower amount of endogenous auxin present in the cuttings of some species may reduce rooting ability (Husen and Pal, 2006; Baul et al., 2010). At the same time, higher level of auxin content in the cutting of some species may lead to increase rooting ability without using of IBA or other growth hormones.

The highest sprouting ability was recognized with $0.8 \%$ IBA treatment $(\mathrm{p}<0.05)$ in this study but number of sprouts per cutting and average number of leaves per cutting were insignificant with IBA treatments. The significance of auxin to enhance rooting ability was well documented (Leakey et al., 1992; Ofori et al., 1996; Berhe and Negash, 1998; Negash, 2002; Tchoundjeu et al., 2002; Tchoundjeu et al., 2004; Abdullah et al., 2006; Husen and Pal 2007; Amri et al., 2009; Baul et al., 2010), but only few documents for the effectiveness of IBA on sprouting ability were available. Husen and Pal (2007) did a study to find out the effect of auxin treatment and branch position on vegetative propagation of Tectona grandis and found significant difference of all parameters of sprouting ability except number of sprouts per cutting. They noticed the highest percent of sprouts and number of sprouts per cutting and number of leaves per cutting in $0.4 \%$ IBA treatment. Different treatments of IBA accelerated rooting and 
sprouting ability of $S$. album though control also prompted very high percent of rooting and sprouting ability of this species. This may be due to $S$. album contents high amount of endogenous auxins in the cuttings. But our study revealed that shoot biomass was higher than root biomass (Figure $01 \& 04$ ) which may be an indicator of endogenous growth hormone present in cutting of $S$. album speed up the growth of shoots than roots.

Our study revealed that the survival of rooted cutting after transfer to polybags was higher for the cutting with control which is very much similar with the findings of Baul et al. (2011). They carried out an experiment on the effect of IBA on vegetative propagation of Litsea monopetala, a wild tropical medicinal plant and found 100\% survival of rooted cutting in control three months after transfer the cutting to polybags. Minadawati and Rostawati (1989) on Agathis loranthifolia, Baul et al. (2008) on Stereospermum suaveolens documented highest survival percent with low concentration of IBA (0.2\%) treatments. It may be due to application of higher concentration of IBA treatments seem to be detrimental for survival for some species. Baul et al. (2010) postulated that higher concentration of IBA treatment may have some negative impacts against naturally occurring growth hormones in the cuttings.

\section{Conclusion}

S. album is a threatened species in the Indian sub-continent, and considered as luxurious tree species for its high class fragrant heartwood which has been used in perfumes, cosmetics and medicine industries. Clonal propagation through branch cutting might be effective method for conservation this valuable species. The study highlights IBA treatments for maximum rooting, sprouting response and survival of rooted cutting after transfer to poly-bags. The rooting and sprouting percent were significantly higher in cuttings treated $0.8 \%$ IBA, though cuttings with control showed very high percentage of rooting and sprouting. However, the survival percentage of rooted cutting was higher in control. Therefore, considering all the results under different treatments, branch cutting with control may be applicable for macro-clonal propagation of this species. Clonal propagation of this species can be a very economical, valuable, efficient and simple way to produce planting materials of desirable attributes for the domestication and to provide sufficient raw materials for perfumes, cosmetics, and medicine industries and also for the rural communities. This experiment disclosed a new idea for the researchers, scientists, farmers for large scale plantation, sustainable uses and conservation of S. album through branch cuttings.

\section{Acknowledgements}

We acknowledge the staff of Forestry and Wood Technology Discipline, Khulna University, Bangladesh for the contribution of propagator construction and support during the experiments.

\section{References}

[1]. Abdullah, A. T. M., Hossain, M. A. \& Bhuiyan, M. K. (2005). Propagation of Latkan (Baccaurea sapida Muell. Arg.) by mature stem cutting. Res. J. Biol. Sci. 1(2), 129-134.

[2]. Abdullah, A. T. M., Hossain, M. A. \& Bhuiyan, M. K. (2006). Clonal propagation of guava (Psidium guajava Linn.) by stem cutting from mature stock plants. J. For. Res. 17(4), 301-304. http://dx.doi.org/10.1007/s11676-006-0069-2

[3]. Alam, M. K. (2001). Rural homesteads: potential areas for production and conservation of medicinal plants in Bangladesh. Bangladesh Forest Research Institute, Chittagong, Bangladesh. pp. 18-20.

[4]. Aminah, H., Dick, J. Mc. P., Leakey, R. R. B., Grace, J. \& Smith, R. I. (1995). Effect of indole butyric acid (IBA) on stem cuttings of Shorea leprosula. Forest Ecology and Management, 72, 199-206.

http://dx.doi.org/10.1016/0378-1127(94)03461-5 
[5]. Amri, E., Lyaruu, H. V. M., Nyomora, A. S. \& Kanyeka, Z. L. (2009). Vegetative propagation of African Blackwood (Dalbergia melanoxylon Guill. \& Perr.): effects of age of donor plant, IBA treatment and cutting position on rooting ability of stem cuttings. New Forests, 39(2), 183-194. http://dx.doi.org/10.1007/s11056-009-9163-6

[6]. Asian Regional Workshop, (Conservation \& Sustainable Management of Trees, Viet Nam, August 1996) (1998). Santalum album. The IUCN Red List of Threatened Species 1998: e.T31852A9665066. http://dx.doi.org/10.2305/IUCN.UK.1998.RLTS.T31852A9665066.en

[7]. Azad, M. S. \& Matin, M. A. (2015). Effect of indole-3-butyric acid on clonal propagation of Swietenia macrophylla through branch cutting. Journal of Botany, 2015, ID. 249308, p. 7. http://dx.doi.org/10.1155/2015/249308

[8]. Batabyal, S., Dalal, T. \& Tah, J. (2014). Responses of some phyto-hormones for vegetative propagation of an ancient precious wood plant: Santalum album L.. Bioscience Discovery, 5, 170174.

[9]. Baul, T. K., Hossain, M. M., Mezbahuddin, M. \& Mohiuddin, M. (2011). Vegetative propagation of Litsea monopetala, a wild tropical medicinal plant: effect of indole-3-butyric acid (IBA) on stem cuttings. J. For. Res. 22(3), 409-416. http://dx.doi.org/10.1007/s11676-011-0111-x

[10]. Baul, T. K., Mezbahuddin, M. \& Mohiuddin, M. (2008). Vegetative propagation and initial growth performance of Stereospermum suaveolens (DC), a wild tropical tree species of medicinal value. New Forests, 37, 375-283.

[11]. Baul, T. K., Mezbahuddin, M., Hossain, M. M. \& Mohiuddin, M. (2010). Vegetative propagation of Holarrhena pubescens, a wild tropical medicinal plant: effect of indole-3-butyric acid (IBA) on stem cuttings. For. Stud. China. 12(4), 228-235. http://dx.doi.org/10.1007/s11632-010-0409-3

[12]. BBS (2001). Bangladesh Population Census, Zilla Series: Khulna. Bangladesh Bureau of Statistics, Statistics Division, Ministry of planning, Government of Bangladesh.

[13]. Berhe, D. \& Negash L. (1998). Asexual propagation of Juniperus procera from Ethiopia: a contribution to the conservation of African pencil cedar. Forest Ecology and Management, 112, 179-190. http://dx.doi.org/10.1016/S0378-1127(98)00327-2

[14]. Dick, J. Mc. P. \& Aminah, H. (1994). Vegetative propagation of tree species indigenous to Malaysia. Commonwealth Forestry Review, 73, 164-171.

[15]. Hartmann, H. T., Kester, D. E., Davies, F. T. \& Geneve, R. L. (2002). Plant propagation: principles and practices. (Seventh Eds). Prentice Hall Inc., Upper SaddleRiver. pp. 176-328.

[16]. Hartmann, H. T., Kester, D. E. \& Davies, F. T. (1990). Plant propagation, principles and practices. New Jersey: Prentice-Hall Inc.

[17]. Husen, A. \& Pal, M. (2006). Variation in shoot anatomy and rooting behaviour of stem cuttings in relation to age of donor plants in teak (Tectona grandis Linn. f.). New Forest, 31(1), 57-73.

http://dx.doi.org/10.1007/s11056-004-6794-5

[18]. Husen, A. \& Pal, M. (2007). Effect of branch position and auxin treatment on clonal propagation of Tectona grandis Linn. f. New Forests, 34, 223-233.

http://dx.doi.org/10.1007/s11056-007-9050-y

[19]. Husen, A. (2003). Effect of IBA and NAA treatments on rooting of Rauvolfia serpentine Benth. Ex Kurz shoot cuttings. Ann. Forestry, 11, 88-93.

[20]. Husen, A., Khali, R., Nautiyal, S. \& Bhandari, H. C. S. (2003). Effects of phytohormones on rooting of nodal shoot cuttings of Grewia optiva Drummond. Ind. Forest. 129, 1147-1152.

[21]. Itoh, A., Yamakura, T., Kanzaki, T. M., Ohkubo, P., Palmiotto, A., LaFrankie, J. V., Kendawang, J. J. \& Lee, H. S. (2002). Rooting ability of cuttings relates to phylogeny, habitat preference and growth characteristics of tropical rainforest trees. Forest Ecology and Management, 168, 275-287.

http://dx.doi.org/10.1016/S0378-1127(01)00742-3

[22]. Jayawardena, M. M. D. M., Jayasuriya, K. M. G. G. \& Walck, J. L. (2015). Confirmation of morphophysiological dormancy in sandalwood (Santalum album, Santalaceae) seeds. J. Natn. Sci. Foundation Sri Lanka, 43, 209-215. http://dx.doi.org/10.4038/jnsfsr.v43i3.7949 
[23]. Kamluddin, M., Ali, M. \& Bhuiyan, M. K. (1996). Effect of auxin on rooting and growth of stecklings of jackfruit (Artocarpus heterophyllus). Chittagong University Studies. Part II: Science, 20(1), 71-75.

[24]. Leakey, R. R. B, Newton, A. C. \& Dick, J. Mc. P. (1994). Capture of genetic variation by vegetative propagation: processes determining success. In: Leakey, R. R. B. \& Newton, A. C. (Eds), Tropical Trees: the Potential for Domestication and the Rebuilding of Forest Resources. London: HMSO, pp. 72-83.

[25]. Leakey, R. R. B., Dick, J. Mc. P. \& Newton, A. C. (1992). Stock plant derived variation in rooting ability: the source of physiological youth. Proceedings of the symposium on mass production technology for genetically improved fast growing forest tree species. Bordeaux, France, 171178.

[26]. Leakey, R. R. B., Mesen, J. F., Tchoundjeu, Z., Longman, K. A., Dick, J. Mc. P. \& Matin, A. (1990). Low technology techniques for the vegetative propagation of tropical trees. Commonwealth Forestry Review, 69, 247-257.

[27]. Matin, M. A., Islam, M. S. \& Azad, M. S. (2006). Seed germination, seedling growth and rooting of branch cuttings of Dalbergia sissoo Roxb. Khulna University Studies (Special Issue 1st Research Cell Conference), 83-87.

[28]. Minadawati, N. \& Rostawati, T. (1989). The influence of container size and color on growth of Agathis loranthifolia seedlings. Bulletin Penelitian Hutun Pusat Penelitian dan Pengerbangan Hutun, 505, 9-10.

[29]. Misra, B. B. \& Dey, S. (2012). Comparative phytochemical analysis and anti-bacterial efficiency of in vitro and in vivo extracts from East Indian sandalwood tree (Santalum album L.). Letters in Applied Microbiology, 55, 476-486. http://dx.doi.org/10.1111/lam.12005

[30]. Misra, B. B. \& Dey, S. (2013a). Biological activities of East Indian sandalwood tree, Santalum album. Peer. J. Pre. Prints. 1, e96v1.

[31]. Misra, B. B. \& Dey, S. (2013b). Evaluation of in vivo anti-hyperglycemic and antioxidant potentials of $\alpha$-santalol and sandalwood oil. Phytomedicine, 20(5), 409-416.

http://dx.doi.org/10.1016/j.phymed.2012.12.017

[32]. Negash, L. (2002). Successful propagation techniques for the threatened African pencil cedar (Uuniperus procera Hoechst. Ex Endl.). Forest Ecology and Management, 161, 53-64.

http://dx.doi.org/10.1016/S0378-1127(01)00501-1

[33]. Ofori, D. A., Newton, A. C., Leakey, R. R. B. \& Grace, J. (1996). Vegetative propagation of Milicia excels by leafy stem cuttings: effects of auxin concentration, leaf area and rooting medium. Forest Ecology and Management, 84, 39-48. http://dx.doi.org/10.1016/0378-1127(96)03737-1

[34]. Opuni-Frimpong, E., Karnosky, D. F., Storer, A. J. \& Cobbinah, J. R. (2008). Key roles of leaves, stockplant age, and auxin concentration in vegetative propagation of two African mahoganies: Khaya anthotheca Welw. and Khaya ivorensis A. Chev. New Forest, 36, 115-123.

http://dx.doi.org/10.1007/s11056-008-9087-6

[35]. Rao, P. S. \& Bapat, V. A. (1992). Micro-propagation of Sandalwood (Santalum album L.). In: Bajaj, Y. P. S. (Eds) Biotechnology in agriculture and forestry. High tech and micropropagation II. vol 18. Springer, Berlin Heidelberg New York. pp. 193-210.

[36]. Rao, P. S. \& Bapat, V. A. (1978). Vegetative propagation of sandalwood plants through tissue cultures. Can. J. Bot. 56, 1153-1156. http://dx.doi.org/10.1139/b78-129

[37]. Rao, P. S. \& Ram, N. V. R. (1983). Propagation of Sandalwood (Santalum Album Linn) using Tissue and Organ Culture Technique. Plant Cell Culture in Crop Improvement, 22, 119-124. http://dx.doi.org/10.1007/978-1-4684-4379-0_13

[38]. Sahai, A. \& Shivanna, K. R. (1984). Seed germination, seedling growth and haustorial induction in Santalum album, a semi-root parasite. Proceedings: Plant Sciences, 94, 571-580.

[39]. Sanjaya, Muthan, B., Rathore, T. S. \& Rai, V. R. (2006). Micropropagation of an endangered Indian sandalwood (Santalum album L.). Journal of forest research, 11, 203-206.

http://dx.doi.org/10.1007/s10310-006-0207-x 
[40]. Shiembo, P. N., Newton, A. C. \& Leakey, R. R. B. (1996). Vegetative propagation of Ricinodendron heudelotii, a West African fruit tree. Journal of Tropical Forest Science, 9, 514-525.

[41]. Singh, C. K., Raj, S. R., Pati, V. R., Jaiswal, P. S. \& Subhash, N. (1913). Plant regeneration from leaf explants of mature sandalwood (Santalum album L.) trees under in vitro conditions. In Vitro Cell. Dev. Biol. Plant. 49, 216-222. http://dx.doi.org/10.1007/s11627-013-9495-y

[42]. Srimathi, R. A., Venkateshan, K. R. \& Kulkarni, H. D. (1995). Guidelines for selection and establishment of seed stand, seed production areas, plus trees and clonal seed orchards for sandal (Santalum album L.). In: Srimathi, R. A., Venkateshan, K. R. \& Kulkarni, H. D. (Eds).Recent advances in research and management of sandal (Santalum album L.) in India. Associated, New Delhi. pp. 281-299.

[43]. Srinivasan, V. V., Sivaramakrishnan, K., Rangaswamy, C. R., Ananthapadmanabha, H. S., Shankara \& Narayana, K. H. (1992). Sandal (Santalum album L.). Institute of Wood Science and Technology. Banglore, India. pp. 1-60.

[44]. Tchoundjeu, Z. \& Leakey, R. R. B. (2001). Vegetative propagation of Lovoa trichilioides: effects of provenance, substrate, auxins and leaf area. Journal of Tropical Forest Science, 13, 116-129.

[45]. Tchoundjeu, Z. \& Leakey, R. R. B. (2000).Vegetative propagation of Khaya ivorensis (African mahogany): effects of stockplant flushing cycle, auxin and leaf area on carbohydrate and nutrient dynamics of cuttings. Journal of Tropical Forest Science, 12(1), 77-91.

[46]. Tchoundjeu, Z., Asaah, E. K., Anegbeh, P., Degrande, A., Mbile, P., Facheux, C., Tsobeng, A., Atangana, A. R., Ngo Mpeck, M. L. \& Simons, A. J. (2006). Putting participatory domestication into practice in West and Central Africa. Forest Trees and Livelihoods. 16, 53-69.

http://dx.doi.org/10.1080/14728028.2006.9752545

[47]. Tchoundjeu, Z., Avana, M. L., Leakey, R. R. B., Simons, A. J., Asaah, E. \& Duguma, B. (2002). Vegetative propagation of Prunus africana: effects of rooting medium, auxin concentrations and leaf area. Agroforestry Systems, 54, 183-192.http://dx.doi.org/10.1023/A:1016049004139

[48]. Tchoundjeu, Z., Mpeck, M. L. N., Asaah, E. \& Amougou, A. (2004). The role of vegetative propagation in the domestication of Pausinystalia johimbe (K. Schum), a highly threatened medicinal species of West and Central Africa. ForestEcology and Management, 188, 175-183. http://dx.doi.org/10.1016/j.foreco.2003.07.010

[49]. Uniyal, D. P., Thapliyal, R. C. \& Rawat, M. S. (1985). Vegetative propagation by root cuttings. Indian Forest, 3, 145-148

[50]. XiaoJin, L., DaPing, X. X., NingNan, Z., Zheng Sheng, X. \& HaoFu, C. (2010). Effects of gibberellins on seed germination and seedling growth of sandalwood (Santalum album). Seed, 29, 71-74.

\section{How to cite this article?}

\section{APA (American Psychological Association)}

Azad, M. S., Alam, M. J., Mollick, A. S. \& Matin, M. A. (2016). Responses of IBA on rooting, biomass production and survival of branch cuttings of Santalum album L., a wild threatened tropical medicinal tree species. Journal of Science, Technology and Environment Informatics, 03(02), 195-206.

\section{MLA (Modern Language Association)}

Azad, M. S., Alam, M. J., Mollick, A. S. \& Matin, M. A. "Responses of IBA on rooting, biomass production and survival of branch cuttings of Santalum album L., a wild threatened tropical medicinal tree species." Journal of Science, Technology and Environment Informatics, 03.02 (2016): 195-206.

\section{Chicago/Turabian}

Azad, M. S., Alam, M. J., Mollick, A. S. \& Matin, M. A. Responses of IBA on rooting, biomass production and survival of branch cuttings of Santalum album L., a wild threatened tropical medicinal tree species. Journal of Science, Technology and Environment Informatics, 03, no. 02 (2016): 195-206. 